\title{
Speed of Reversion to PPP with Structural Breaks for Brazilian Cities
}

\author{
Felipe S. Bastos ${ }^{1}$, Elano F. Arruda ${ }^{2}$, Rafael B. Barbosa ${ }^{3} \&$ Roberto T. Ferreira ${ }^{4}$ \\ ${ }^{1} \mathrm{PhD}$ Candidate (CAEN/UFC), Brazil \\ ${ }^{2}$ Department of Applied Economics (DEA/MAER/CAEN/UFC), Brazil \\ ${ }^{3}$ Department of Applied Economics (DEA/UFC), Brazil \\ ${ }^{4}$ Department of Applied Economics (DEA/CAEN/UFC), Brazil \\ Correspondence: Felipe S. Bastos, Avenida da Universidade, 2700 - $2^{\circ}$ Floor. Zip code: 60020-181. Benfica - \\ Fortaleza/CE. Phone: (85) 3366-7751. E-mail: flpsbastos@gmail.com
}

Received: January 19, 2018

Accepted: February 7, 2018

Online Published: February 28, 2018

doi:10.5539/ijef.v10n4p15

URL: https://doi.org/10.5539/ijef.v10n4p15

\begin{abstract}
This article analyzes the effect of introducing structural breaks in calculating the convergence speed of relative prices for Brazilian cities in the period from 1991.01 to 2016.11. Three structural break dates were endogenously chosen (1996.02, 2001.12 and 2010.10) and they represent different situations of the Brazilian economy, with impacts on intra-national relative prices. The convergence speed, measured by the half-life, declined by approximately $77 \%$ after controlling for these structural changes. The result was robust to changes in numeraire both for calculation of the half-life and estimation of the structural break dates, and indicates the importance of considering structural breaks in calculating intra-national purchasing power parity, as found in other studies.
\end{abstract}

Keywords: purchasing power parity, structural breaks, nickell bias, aggregation bias, Brazilian cities

\section{Introduction}

The theory of purchasing power parity (PPP) can be defined as a generalization of the law of one price, which says that the prices of a good must be identical when measured in the same currency. In this respect, PPP, in its absolute version, states that this holds true not only for a single good, but for all the goods in the economy, so that the average prices (Note 1) of two different economies should be equal when measured in a single currency.

Formally stated, the theory posits that under perfect competition, arbitrage in the market for goods will generate general equalization of prices, so that the real exchange rates will return, over the long run, to a common stationary value. Due to its importance as an assumption in international macroeconomic models, many studies have been conducted to check its validity (Note 2).

Authors have used distinct datasets and methods to verify the validity of PPP. In a survey of the area, Rogoff (1996) presented the problem known as the PPP puzzle which is associated with the fact that either it is not possible to reject the presence of a unit root in the real exchange rate series or the observed reversion speeds of deviations from PPP are very slow, taking 3 to 5 years.

The use of intra-national have the advantages of minimizing the effects of transport costs, tariff and non-tariff barriers, monetary policy asymmetries, nominal exchange rate fluctuations and heterogeneity of consumption baskets (Note 3) in the PPP analysis. Engel and Rogers (1996) and Parsley and Wei (1996) were the pioneers in investigating the validity and regularity of PPP with data on cities. The former authors verified the validity of the law of one price, fundamental for the PPP theory, while the latter provided estimates of the rate of convergence of deviations from PPP relying on data from American cities.

Choi, Mark and Sul (2006), henceforth CMS (2006), showed that there are three possible sources of bias in the estimation of half-lives (Note 4) through panel data: Nickell, temporal aggregation and heterogeneity bias. They proposed ways of correcting these problems that provided lower values for half-lives. Besides, authors such as Basher and Carrion-i-Silvestre (2011), Hegwood and Nath (2013) and Nath and Sarkar (2014) showed a substantial reduction in the estimate of this measure by including structural breaks in the analysis.

Until now, few studies have sought evidence about the speed of reversion to PPP with Brazilian intra-national data, and none has considered the presence of structural breaks. Bastos, Arruda and Ferreira (2014), henceforth 
BAF (2014), reported a median half-life of approximately 3.13 years considering the 11 metropolitan regions covered by the survey used to compute the Consumer Price Index (IPCA) as numeraires. Arruda et al. (2015) found average half-lives of 19, 27 and 42 months when using, respectively, the mean IPCA of the cities, the national IPCA and the IPCA of São Paulo as numeraires.

Therefore, this study estimates the speed of reversion to PPP for Brazilian cities with corrections for the biases of Nickell, temporal aggregation and structural breaks, following Hegwood and Nath (2013) and Nath and Sarkar (2014), considering monthly Consumer Price Index (IPCA) data for Brazilian cities between 1991.01 and 2016.11.

The results indicate the presence of structural breaks in 1996.02, 2001.12 and 2010.10. These three dates marked the start of important developments in the Brazilian economy that might have affected the dynamics of relative prices, namely: consolidation of the Real Plan (economic stabilization (Note 5) plan), implementation of inflation targeting and recent changes in monetary policy orientation. The estimated half-lives suggest a significant reduction of the rate of reversion to PPP for Brazilian cities. For example, considering Brazil as a whole, the mean and São Paulo, the half-lives without considering the structural breaks were 22, 17 and 23 months, respectively. After including the three breaks, these intervals declined to 4.2, 4.8 and 7.5 months, respectively, in line with the considerable reductions found by Hegwood and Nath (2013) and Nath and Sarkar (2014).

Besides this introduction, the article has four more sections. The next section presents a review of the literature on analysis of the convergence of intra-national relative prices. The third section describes the database and the econometric strategy utilized, while the fourth section presents and discusses the results. The fifth section presents our final remarks.

\section{Review of the Literature}

In a pioneering study for cities, Engel and Rogers (1996), to examine the nature of the deviations from the law of one price, used data from the Consumer Price index (CPI) for 14 categories of consumer goods in 14 American cities and 9 cities in Canada. They found that the distance between cities causes positive effect on the volatility of relative prices among them.

Parsley and Wei (1996) estimated an upper bound for the rate of convergence to purchasing power parity using a panel with quarterly price data from 48 American cities from 1975:01 to 1992:04. Dividing the prices into groups of tradable (perishable and non-perishable) and non-tradable goods, they computed the half-lives based on the median of the autoregressive coefficients of each group, obtaining reversions of approximately 5,4 and 15 quarters for non-perishables, perishables and non-tradables, respectively. The authors also presented evidence of non-linearity in the convergence rates, since the convergence occurred faster with large initial gaps in prices.

Culver and Papell (1999), with data from the post-Bretton-Woods era, found weak evidence of the validity of PPP with intra-national data, comparing those obtained for North American and European countries. The speed of reversion of deviations from PPP was slower in the United States than in Canada and European countries. In other words, even without the problems posed by trade barriers, exchange rate volatility, monetary policy asymmetries and other factors that restrict arbitrage in the market for goods, they found a slow convergence process of prices in the United States.

To investigate the persistence of deviations from PPP, Nenna (2001) employed monthly data from Italian capital cities in the 1947-2000 period and obtained a half-life for reversion of deviations from PPP of 23.6 months. Besides this, she reported evidence supporting the presence of the Harrod-Balassa-Samuelson effect (Note 6) and of transportation costs as determinants of the slow adjustment of relative prices.

Cecchetti, Mark and Sonora (2002) used panel data of price indexes for 19 American cities in the period from 1918 to 1995. They found a slow pace of reversion of deviations from PPP, with a half-life of approximately 9 years. They explain this slow process of price adjustment by a combination of the presence of transportation costs, differential adjustment speeds to large and small shocks, and the inclusion of non-tradable goods in the computation of the general price index.

Chen and Devereux (2003) found strong evidence that the prices for 19 American cities during the interval from 1918 to 2000, converged over time and that the dispersion of the price levels for these cities (within the same country) was lower than that for countries of the OECD. They also stated that the non-stationarity of the real exchange rate is not evidence against the validity of PPP when checking the convergence of prices, since the real exchange rate of the cities may not return to a fixed mean. Hence, that evidence is consistent with a broader version of PPP that permits reductions in transportation costs and improved market integration. 
Carrion-i-Silvestre, Del Barrio and López-Bazo (2004), in a study of 50 Spanish cities in the period from 1937 to 1992, found evidence in favor of PPP rejecting the null hypothesis of the presence of a unit root in three of four tests applied. Due to a median half-life of 3.6 years, the authors suggested further studies to explain the slow pace of adjustment of deviations from PPP for regions with a common currency and trade.

Using data from 35 Mexican cities covering the period from 1982 to 2000, Sonora (2005) examined the convergence of the price level for a country with moderately high inflation, stressing that economies in this situation generally converge more quickly to the equilibrium exchange rate. The results of the unit root tests did not reject the hypothesis of PPP and presented an estimated half-life of 2 to 3 years. Besides this, to analyze PPP in more homogeneous areas in terms of preferences and productivity, he divided the sample into regions and obtained regional half-lives in the interval from 1.7 to 7 years.

CMS (2006), pointed out the existence of three potential sources of bias introduced by the structure of panel data in estimating the half-life of deviations from purchasing power parity, namely inappropriate cross-sectional aggregation of heterogeneous coefficients, small sample estimation bias of dynamic lag coefficients (Nickell bias), and bias induced by time aggregation of commodity prices (Note 7).

Choi and Matsubara (2007) found, through time series and nonlinear models, persistence in the speed of convergence of relative intercity prices in Japan for different types of tradable goods, and observed that regardless of the measure of persistence used, the medians of the half-lives were shorter than 2 years for the great part of the price indexes considered. They presumed that the extent of the heterogeneity among the items of the CPI is related to the degree of tradability and structure of the market, while the physical distance and relative size of the cities can affect the heterogeneity among cities.

Nath and Sarkar (2009) did not find evidence of heterogeneity bias in annual Consumer Price Index (CPI) data for 17 American cities in the interval from 1918 to 2006. Just as CMS (2006), they applied correction for Nickell bias and time aggregation bias to the data, finding a half-life of 7.5 years, shorter than those estimated in previous studies, but still slow.

Das and Bahattacharya (2008) utilized panel data unit root tests robust to cross-sectional dependence for Indian cities from 1995:01 to 2004:06. Decomposing each series into a set of common factors and idiosyncratic components, they estimated half-lives of 8.14 and 22.89 months for shocks on the common and idiosyncratic components, respectively.

With data covering nearly the entire period of European integration (1960-2003), Faber and Stokman (2009) observed evidence that European price levels converged to the common long-term levels in the United States. Among the determinants of the dispersion of European price levels, they stressed that indirect taxes and convergence of traded and non-traded input costs contributed, to different extents and degrees of variation, to the price level convergence time.

To examine whether the choice of numeraire has an impact on the relative price dynamics of American cities, Chmelarova and Nath (2010) modeled the real exchange rate between cities as being composed of two components: a factor common to all the cross-sections and another idiosyncratic component. The results obtained suggested that the dynamic behavior of relative prices indeed depends on the numeraire city chosen. Finding estimated half-lives of 7.60 to 11.18 years, the authors also stressed that with correction for the Nickell and temporal aggregation biases, as suggested by CMS (2006), the half-lives obtained were shorter than those presented in a series of previous studies.

Controlling for multiple structural breaks in the data for 17 American cities in the period from 1918 to 2005, Basher and Carrion-i-Silvestre (2011) reported a median half-life in the interval of 1.5 to 2.6 years. They pointed out that long time series are subject to structural breaks and that failure to deal with these can lead to overestimation of the autoregressive coefficient, and consequently the speed of reversion to PPP. These results were lower than the interval proposed by Rogoff (1996) and the half-lives obtained in previous studies of American cities.

Hegwood and Nath (2013) used unit root tests that incorporated a structural break and applied this method to longitudinal data from 17 cities in the United States between 1918 and 2010. They reported evidence of convergence of relative prices of the cities. Employing corrections for the Nickell and temporal aggregation biases, they also found a half-life of approximately 3.9 years, substantially shorter than those obtained previously by Cecchetti, Mark and Sonora (2002), Nath and Sarkar (2009) and Chmelarova and Nath (2010).

Employing quarterly data over the interval from 1972 to 2011 for seven Australian cities, Nath and Sarkar (2014) applied unit root tests that allowed the presence of multiple endogenously determined breaks. With regime 
changes in 1985, 1995 and 2007, the authors obtained half-lives in the interval of 2.3 to 3.8 quarters, leading them to conclude that besides correction for biases, allowing for regime changes in the relative price series is an important aspect to reduce the half-lives in the PPP empirical analysis.

For the Brazilian economy, only a few studies have analyzed the half-life for convergence in an intra-national (Note 8) context. BAF (2014) estimated the convergence half-life for the Brazilian economy using data from the Consumer Price Index (IPCA) for 11 cities over the period from 1991.01 to 2013.09. As CMS (2006), they corrected the estimates for the Nickell and temporal aggregation biases and obtained a median half-life of 3.13 years, ranging from 2.55 to 3.84 years, slightly shorter than that proposed by Rogoff (1996).

Arruda et al. (2015) analyzed the evolution of relative prices of Brazilian cities from 1995 to 2012 to identify stylized facts on the convergence of prices and speed of reversion to PPP. They found evidence of a reduction in the absolute dispersion of the prices in Brazilian cities and the variability of relative prices. When São Paulo, Brazil as a whole and the mean of cities are used as numeraires, they observed half-lives of 42, 27 and 19 months, respectively.

\section{Methodological Aspects}

We use monthly data of Consumer Price Index (IPCA) for 11 Brazilian cities (Note 9), covering the period from 1991.01 to 2016.11. All data are from the Brazilian Institute of Geography and Statistics (IBGE). Let $P_{i t}$ be the price index of city $i$ in period $t$ and $P_{n, t}$ be the price index of the numeraire city for the same period $t$. Then the relative price defined by:

$$
r_{i t}=100 \times\left(\ln P_{i t}-\ln P_{n, t}\right)
$$

The econometric strategy is based on Nath and Sakar (2014) and Hegwood and Nath (2013). This method consists of two steps. In the first, a unit root test is applied to panel data to identify the dates of the structural breaks, if any. The second step involves application of panel methods to calculate the half-life of convergence between the periods defined by the breaks. This procedure also corrects the calculation of the half-life for the presence of the Nickell and temporal aggregation biases (Note 10), as proposed by CMS (2006).

The method to identify the structural breaks is an adaptation for panel data of the Additive-Outlier (AO) form developed by Perron and Vogelsang (1992). First, assuming the presence of $m$ structural breaks, the following panel model is estimated:

$$
r_{i, t}=\mu_{i}+\sum_{l=1}^{m} \theta_{l, i} D I_{l, t}+u_{i, t}
$$

where: $D I_{l, t}$ is a dummy variable for structural break $l$ on date $t$, i.e., $D I_{l, t}=1$ for all $t$ after the $l-t h$ break. The structural breaks permitted in (2) consist only of instabilities in the intercept. There is no testing of the presence of instabilities in the trend, since models with trend are not consistent with the PPP theory.

Another characteristic of this test is the imposition that the date of the break be the same for all cities. In other words, the idea is to find periods delineated by structural breaks that are common to all the cities considered. Thus, it is possible for a city to have particular breaks. An advantage of adopting this procedure is that common instabilities are more closely associated with national shocks, and thus less related to local traits. In this way, it is possible to contextualize the periods with events that occurred in the Brazilian economy.

Next, a unit root test of the ADF type is performed for the residuals of (2), as follows:

$$
\Delta u_{i, t}=\alpha u_{i, t-1}+\sum_{j=1}^{k_{l}} c_{i, j} \Delta u_{i, t-j}+\varepsilon_{i, t}
$$

Let $k^{\max }$ and $m^{\max }$ be the maximum number lags of the difference of $u_{i, t}$ and the maximum number of breaks allowed, respectively, so (2) and (3) are estimated sequentially for reach possible break: $q_{l}=k^{\max }+$ $\left(k_{i} \times m\right), \ldots, T-\left\{k_{i} \times\left(m^{\max }-m\right)\right\}-1$, where $k_{i}=8$ and $T$ is the total number of periods for all the cities. The period that minimizes the test $t$ for $\alpha$ will be chosen as the structural break date. The critical values for this hypothesis test are obtained by Monte Carlo methods.

\subsection{Estimation of the Half-Life}

The half-life measures the time that a unit shock in a given time series takes to dissipate by half. According to Imbs et al. (2005), this is the unit most often used to measure the reversion speed to PPP in scientific articles in this area.

Consider a stochastic process $A R(k)$ whose dependent variable is the relative price between two cities: $r_{i t}=\mu_{i}+\rho r_{i t-1}+\sum_{j=2}^{k} c_{i} r_{i t-j}+e_{i t}$ where $e_{i t}$ is a process with zero mean. If the order $k$ is chosen appropriately (Note 11), and assuming the same order for all the transversal units (Note 12), then the half-life of convergence is defined by: 


$$
H(\rho)=\frac{\ln (0.5)}{\ln (\rho)}
$$

where $\rho=\alpha+1$ (Note 13). We estimate a panel model with fixed effects, controlling for structural breaks and cross-sectional dependence, using the following regression:

$$
r_{i t}=\mu_{i}+\sum_{l=1}^{m} \theta_{l, i} D I_{l, t}+\rho r_{i t-1}+\sum_{j=2}^{k} c_{i} r_{i t-j}+e_{i t}
$$

where $D I_{l, t}=1$ for all $t$ after the $l$-th break. The error of (5) is allowed to follow a MA(1) process with cross sectional dependence, such as:

$$
u_{i t}=v_{i t}+\gamma v_{i t-1} \quad \text { and } \quad v_{i t}=\delta_{i} \varphi_{t}+\omega_{t}
$$

where: $\delta_{i}$ are the factor loadings, $\varphi_{t}$ are factors that identify shocks common to all cities, and $\omega_{t}$ is a normally distributed and mutually independent error term. This form of including the common factors was adapted by Nath and Sakar (2014) based on the method proposed by Phillips and Sul (2004).

The supposition of common factors in equation (5) is important since regional analyses present strong evidence of cross-sectional dependence, as noted in Kim and Oka (2013) and Gobillon and Magnac (2015). In other words, regions in the same country are affected by common shocks and these shocks differ between cities only by the idiosyncratic component and the factor loadings.

These equations are estimated iteratively by the generalized least squares (GLS). Subsequently, the estimates of equation (5) are adjusted to correct for the presence of Nickell and temporal aggregation biases, as in CMS (2006) and Nath and Sakar (2014).

\section{Analysis and Discussion of the Results}

Table 1 reports the results of the estimation of the dates of breaks considering the city of São Paulo as reference (Note 14). We find evidence of three structural breaks in 1996.02, 2001.12 and 2010.10. Figure 1 shows the evolution of the series of relative prices with São Paulo as numeraire, with the structural breaks indicated.

Table 1. Structural breaks identification

\begin{tabular}{cccccc}
\hline \multirow{2}{*}{ Breaks number } & \multirow{2}{*}{ Statistic } & \multicolumn{3}{c}{ Critical Values } & Break Dates \\
\cline { 3 - 5 } & & $1 \%$ & $5 \%$ & $10 \%$ & - \\
3 & 0.7138 & -5.5325 & -4.8448 & -4.4347 & $1996.02 / 2001.12 / 2010.10$ \\
\hline
\end{tabular}

Source: Elaborated by the authors.

Note. The critical values were estimated using a Monte Carlo procedure.

The first structural break identified appears to be related to the implementation of the Real Plan, a stabilization plan that promoted a steep decline of inflation throughout the country. The second structural break occurred in 2001.12, coincides with a period of sharp depreciation of the exchange rate and negative expectations regarding maintenance of the macroeconomic conditions, producing inflationary pressures that were later attenuated. Finally, the third structural break occurred in 2010.10. During this period the global economy, especially the European, was negatively affected by the contagion from the subprime crisis in the USA. 


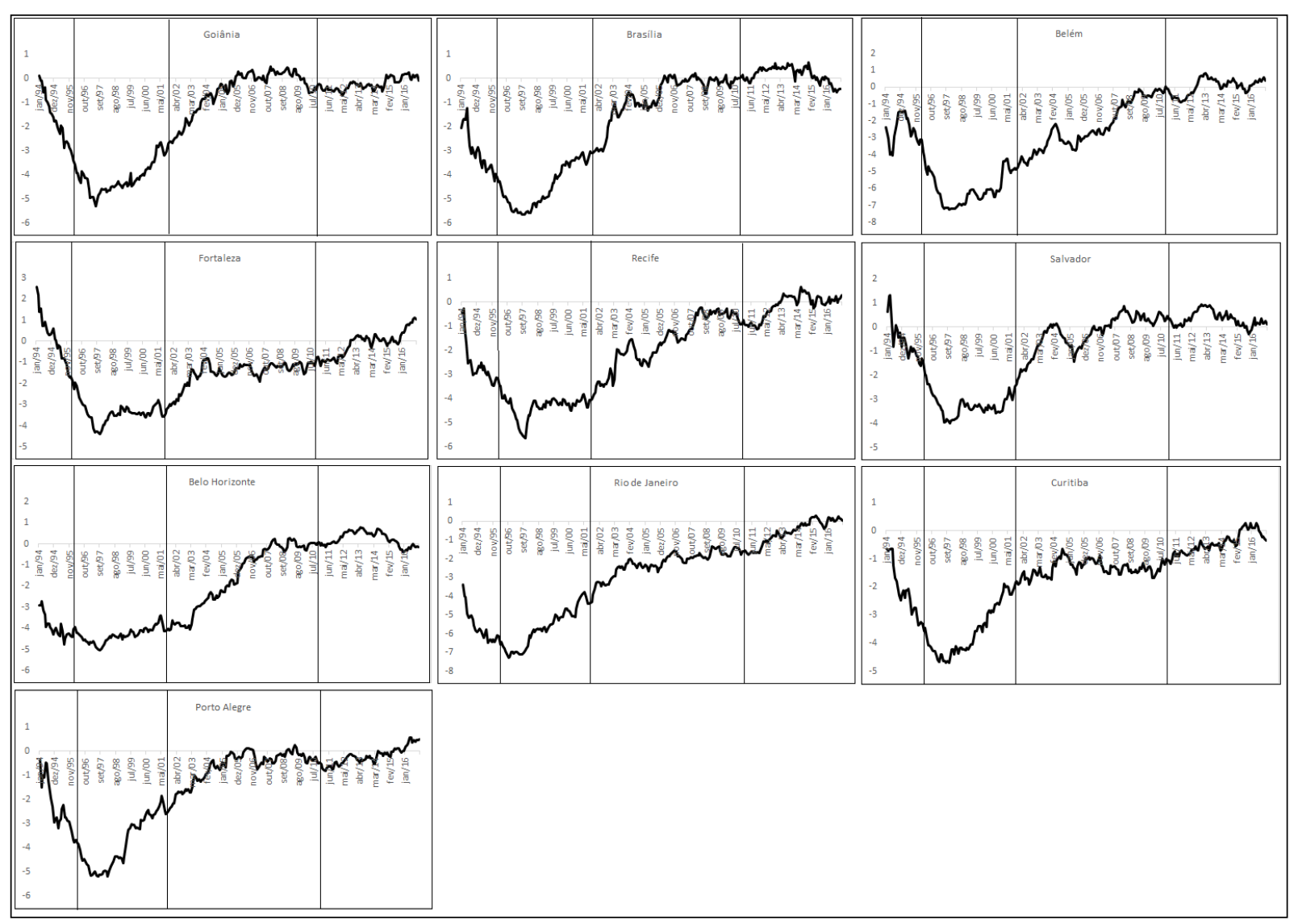

Figure 1. Behavior of relative price series for cities

Source: Elaborated by the authors.

To confirm the robustness of the estimation of the dates of the structural breaks, Table 2 presents the results of the same exercise to identify those dates assuming different numeraires. We estimated the case assuming the presence of three structural breaks based on the average IPCAs of the Brazilian cities considered and the IPCA for Brazil as a whole as the numeraires.

The break dates showed little variation. Considering the average of the cities as numeraire, these dates were 1998.01, 2003.06 and 2009.11. In turn, when considering the nationwide IPCA as numeraire, the dates of the breaks were 1996.06, 2003.01 and 2010.01.

Table 2. Robust of the criteria identification test

\begin{tabular}{lccccc}
\hline \multirow{2}{*}{ Numeraire } & \multirow{2}{*}{ Statistic } & \multicolumn{3}{c}{ Critical Values } & \multirow{2}{*}{ Break Dates } \\
\cline { 3 - 5 } & & $1 \%$ & $5 \%$ & $10 \%$ & \\
\hline$I P C A$ Mean & -7.5797 & -6.9233 & -6.3662 & -6.1856 & $1998.01 / 2003.06 / 2009.11$ \\
$I P C A$ Brasil & -7.5995 & -6.9113 & -6.3942 & -6.1906 & $1996.06 / 2003.01 / 2001.01$ \\
\hline
\end{tabular}

Source: Elaborated by the authors.

Note. The critical values were estimated using a Monte Carlo procedure.

In both cases, the economic reasons indicated to explain the periods demarcated by the structural breaks are apparently the same as in the case considering the city of São Paulo as numeraire. This result indicates that the timing of the estimated structural breaks is insensitive to the numeraire chosen, allowing estimation of the half-life of convergence to be done with different numeraires.

The results of the half-lives estimates are summarized in Table 3. In this table $H(\hat{\rho})$ denotes the value of the half-life of reversion to PPP with each of the cities as numeraire, as well as the Brazil as a whole and the average of the cities. 
Table 3. Half-Lives panel estimation

\begin{tabular}{|c|c|c|c|c|c|c|}
\hline \multirow{2}{*}{ Numeraire } & \multicolumn{2}{|c|}{ Zero Break $^{\mathrm{a}}$} & \multicolumn{2}{|c|}{ Three Breaks $^{\mathrm{a}}$} & \multicolumn{2}{|c|}{ Three Breaks $^{\mathrm{b}}$} \\
\hline & $\hat{\rho}$ & $H(\hat{\rho})$ & $\hat{\rho}$ & $H(\hat{\rho})$ & $\hat{\rho}$ & $H(\hat{\rho})$ \\
\hline São Paulo & 0.970 & 23.076 & 0.912 & 7.512 & 0.941 & 11.360 \\
\hline Goiânia & 0.968 & 21.129 & 0.496 & 0.988 & 0.883 & 5.550 \\
\hline Brasília & 0.964 & 18.972 & 0.845 & 4.112 & 0.970 & 22.750 \\
\hline Belém & 0.961 & 17.582 & 0.848 & 4.212 & 0.895 & 6.270 \\
\hline Fortaleza & 0.965 & 19.290 & 0.852 & 4.334 & 0.953 & 14.310 \\
\hline Recife & 0.965 & 19.354 & 0.855 & 4.421 & 0.989 & 60.990 \\
\hline Salvador & 0.963 & 18.426 & 0.866 & 4.813 & 0.979 & 32.500 \\
\hline Belo Horizonte & 0.961 & 17.214 & 0.869 & 4.955 & 0.915 & 7.780 \\
\hline Rio de Janeiro & 0.962 & 17.966 & 0.872 & 5.051 & 0.213 & 0.449 \\
\hline Curitiba & 0.964 & 18.725 & 0.848 & 4.206 & 0.991 & 78.400 \\
\hline Porto Alegre & 0.961 & 17.528 & 0.851 & 4.285 & 0.939 & 11.000 \\
\hline Brasil & 0969 & 22.102 & 0.849 & 4.234 & 0.969 & 22.174 \\
\hline Mean & 0.961 & 17.422 & 0.866 & 4.805 & 0.971 & 23.350 \\
\hline Minimum & 0.961 & 17.214 & 0.496 & 0.988 & 0.213 & 0.449 \\
\hline Maximum & 0.970 & 23.076 & 0.912 & 7.512 & 0.991 & 78.400 \\
\hline Mean & 0.964 & 19.024 & 0.829 & 4.444 & 0.883 & 23.705 \\
\hline Median & 0.964 & 18.725 & 0.852 & 4.334 & 0.941 & 11.36 \\
\hline
\end{tabular}

Source: Elaborated by the authors.

Note. $H(\hat{\rho})$ denotes the half-lives estimations. ${ }^{a}$ with Nickell and Time Aggregation bias corrections. ${ }^{\mathrm{b}}$ without Nickell and Time Aggregation bias corrections.

Initially, it can be seen that, the estimations without correction for the Nickell and temporal aggregation biases tend to overestimate the half-lives, except when Rio de Janeiro is the numaraire. Therefore, as pointed out by CMS (2006), it is necessary to incorporate correction for these two biases in the process of estimating the reversion to PPP.

Additionally, there is a sharp reduction in the half-lives when considering the structural breaks. The results indicate a median half-life of 18.72 months when only correcting for the Nickell and temporal aggregation biases. In turn, when considering all three structural breaks, this value decreases to 4.33 months, or a median half-life that is $76.87 \%$ shorter.

These results are also shorter than those observed in the literature for Brazilian cities. BAF (2014) found a half-life interval between 30.60 and 46.08 months and Arruda et al. (2015) observed half-lives ranging from 19 to 60 months. Therefore, as argued by Basher and Carrion-i-Silvestre (2011), Hegwood and Nath (2013) and Nath and Sarkar (2014), the estimation of the speed of convergence of relative prices among cities without considering structural breaks (when they exist) will likely produce overestimated half-lives.

The results also indicate that even though other authors have found that half-lives for city-level data can be sensitive to the choice of numeraire, within the limits of 17.21 to 23.07 months (without structural breaks) and 0.98 to 7.5 months (considering three structural breaks), the choice of numeraire does not seem to have a strong influence on the speed of reversion to PPP for Brazilian cities.

Furthermore, without considering structural breaks, the interval of half-lives for Brazilian cities is smaller than those obtained for Mexican cities by Sonora (2005), for American cities by Cecchetti, Mark and Sonora (2002), Chen and Devereux (2003) and Nath and Sakar (2009), and for Spanish cities by Carrion-i-Silvestre, Del Barrio and López-Barro (2004).

When considering the structural breaks, the reversion to PPP for the Brazilian cities was also faster than observed for American cities by Basher and Carrion-i-Silvestre (2011) and Hegwood and Nath (2013), for Japanese cities by Choi and Matsubara (2007), and similar to that observed by Nath and Sarkar (2014) for Australian cities.

\section{Final Considerations}

The aim of this study was to obtain estimates of the speed of reversion of deviations from purchasing power parity for 11 Brazilian cities, considering the existence of structural breaks, Nickell and temporal aggregation biases.

The structural break tests identified the occurrence of three breaks in the sample period (1991.01 to 2016.11). The periods demarcated by these breaks are coherent with periods of changes in the Brazilian economic conjuncture, as 
described in the article.

The estimated half-lives, without structural breaks, using Brazil as a whole and the average price levels of the cities as numeraires, were 22.10 and 17.42 months, respectively. The median of this indicator considering each of the cities individually as numeraire was 18.72 months, varying in the interval from 17.21 to 23.07 months.

Under similar conditions, when considering the three structural breaks observed, the half-lives of reversion considering Brazil as a whole (4.23 months) and the mean of the cities (4.8 months) as numeraires, were far shorter than those observed with correction for Nickell and temporal aggregation biases. Considering each of the 11 cities, the median of this indicator was 4.33 months, a reduction of $76.87 \%$ in the speed of reversion to PPP for Brazilian cities. Therefore, the calculation of the half-lives of convergence of relative prices among cities needs to include the existence of structural breaks, if they exist, under risk of producing results that are strongly overestimated.

\section{References}

Aguiar, M., \& Gopinath, G. (2007). Emerging markets business cycles: The cycle is the trend. Journal of Political Economy, 115, 69-102. https://doi.org/10.1086/511283

Arruda, E., Barbosa, R. B., Guimarães, D. B., \& Castelar, I. (2015). Price Convergence, Reversal Speed and Purchasing Power Parity: Stylized Facts for Brazilian Cities. In XVII Encontro de Economia da Região Sul - XVII ANPEC SUL, Maringá.

Barbosa, F. H. (2009). A Paridade do Poder de Compra: Existe um quebra-cabeça? Estudos Econômicos, 39, 469-487. https://doi.org/10.1590/S0101-41612009000300001

Basher, S. A., \& Carrion-I-Silvestre, J. L. (2011). Measuring Persistence of U.S. City Prices: New Evidence from Robust Tests. Empirical Economics, 41, 739-745. https://doi.org/10.1007/s00181-010-0388-1

Bastos, F. S., Arruda, E. F., \& Ferreira, R. T. (2014). Velocidade de Reversão dos Desvios da Paridade do Poder de Compra para Cidades Brasileiras. In 12th Congress of the Brazilian Regional Science Association - XII ENABER - and 2nd Ibero-American Congress on Regional Development, Belo Horizonte.

Carrion-I-Silvestre, J. L., Del Barrio, T., \& López-Bazo, E. (2004). Evidence On The Purchasing Power Parity In A Panel Of Cities. Applied Economics, 36, 961-966. https://doi.org/10.1080/0003684042000233186

Cecchetti, S. G., Mark, N. C., \& Sonora, Robert J. (2002). Price Index Convergence Among United States Cities. International Economic Review, 43, 1081-1099. https://doi.org/10.1111/1468-2354.t01-1-00049

Chen, L. L., \& Devereux, J. (2003). What Can Us City Price Data Tell Us About Purchasing Power Parity? Journal of International Money and Finance, 22, 213-222. https://doi.org/10.1016/S0261-5606(02)00102-X

Chmelarova, V., \& Nath, H. K. (2010). Relative Price Convergence Among Us Cities: Does The Choice Of Numeraire City Matter? Journal of Macroeconomics, 32, 405-414. https://doi.org/10.1016/j.jmacro .2009.09.006

Choi, C. Y., \& Matsubara, K. (2007). Heterogeneity in the Persistence of Relative Prices: What do the Japanese Cities Tell Us? Journal of the Japanese and International Economies, 21, 260-286. https://doi.org/10.1016/j.jjie.2006.03.002

Choi, C. Y., Mark, N. C., \& Sul, D. (2004). Bias Reduction By Mean Adjustment In Dynamic Panel Data Models. Manuscript, University of Auckland.

Choi, C. Y., Mark, N. C., \& Sul, D. (2006). Unbiased Estimation Of The Half-Life To PPP Convergence In Panel Data. Journal of Money, Credit and Banking, Cambridge, 38, 921-938. https://doi.org/10.1353/mcb.2006.0052

Culver, S. E., \& Papell, D. H. (1999). Panel evidence of purchasing power parity using intra-national and international data. Manuscript, Department Of Economics, University Of Houston.

Das, S., \& Bahattacharya, K. (2008). Price Convergence Across Regions In India. Empirical Economics, 34, 299-313. https://doi.org/10.1007/s00181-007-0123-8

Engel, C., \& Rogers, J. H. (1996). How Wide Is The Border? The American Economic Review, 86, 1112-1125.

Faber, R. P., \& Stokman, A. C. J. (2009). A short history of price level convergence in Europe. Journal of Money, Credit and Banking, 41. https://doi.org/10.1111/j.1538-4616.2009.00215.x

Frankel, J. A. (1986). International capital mobility and crowding-out in the U.S. Economy: Imperfect integration of financial markets or of goods markets? How Open Is The U.S. Economy, 33-74. 
Frankel, J. A., \& Rose, A. K. (1995). A Panel Project On Purchasing Power Parity: Mean Reversion Within And Between Countries. Working Paper, National Bureau of Economic Research. https://doi.org/10.3386/w5006

Freixo, C. S., \& Barbosa, F. H. (2004). Paridade Do Poder De Compra: O Modelo De Reversão Não Linear Para O Brasil. Revista Economia, 5, 75-116.

Hegwood, N. D., \& Nath, H. K. (2013). Structural Breaks And Relative Price Convergence Among Us Cities. Journal of Macroeconomics, 36, 150-160. https://doi.org/10.1016/j.jmacro.2012.12.006

Holland, M., \& Valls Pereira, P. L. (1999). Taxa de Câmbio Real e Paridade de Poder de Compra no Brasil. Revista Brasileira de Economia, 53, 259-285.

Imbs, J., Mumtaz, H., Ravn, M. O., \& Rey, H. (2005). PPP Strikes Back: Aggregation and the Real Exchange Rate. Quarterly Journal of Economics, 120, 1-43.

Kannebley Jr., S. (2003). Paridade do Poder de Compra no Brasil - 1968 a 1994. Estudos Econômicos, 33, 735-769. https://doi.org/10.1590/S0101-41612003000400005

Kendall, M. G. (1954). Note on Bias in the Estimation of Autocorrelation. Biometrika, 41, 403-404. https://doi.org/10.1093/biomet/41.3-4.403

Marçal, E. F., Valls Pereira, P. L., \& Santos Filho, O. C. (2003). Paridade do Poder de Compra: Testando Dados $\begin{array}{lllll}\text { Brasileiros. Revista Brasileira de } & \text { Economia, }\end{array}$ https://doi.org/10.1590/S0034-71402003000100006

Nath, H. K., \& Sarkar, J. (2009). Unbiased Estimation of the Half-life to Price Index Convergence among U.S. Cities. Journal of Money, Credit and Banking, 41, 1041-1046. https://doi.org/10.1111/j.1538-4616.2009.00245.x

Nath, H. K., \& Sarkar, J. (2014). City Relative Price Dynamics in Australia: Are Structural Breaks Important? Economic Record, 90, 33-48. https://doi.org/10.1111/1475-4932.12077

Nenna, M. (2001). Price Level Convergence among Italian Cities: Any Role for the Harrod-Balassa-Samuelson Hypothesis? Working Paper, Ministero dell'Economia e delle Finanze, Consiglio degli Esperti e Faculty of Economics, University of Rome La Sapienza.

Nickell, S. (1981). Biases in Dynamic Models with Fixed Effects. Econometrica, 49, 1417-1426. https://doi.org/10.2307/1911408

Palaia, D., \& Holland, M. (2010). Taxa de Câmbio e Paridade de Poder de Compra no Brasil: Análise Econométrica com Quebra Estrutural. Economia Aplicada, 14, 5-24.

Papell, D. H., \& Theodoridis, H. (2001). The Choice of Numeraire Currency in Panel Tests of Purchasing Power Parity. Journal of Money, Credit and Banking, 33, 790-803. https://doi.org/10.2307/2673894

Parsley, D. C., \& Wei, S. J. (1996). Convergence to the Law of One Price without Trade Barriers or Currency Fluctuations. Quarterly Journal of Economics, 111, 1211-1236. https://doi.org/10.2307/2946713

Pesaran, M. H., \& Yamagata, T. (2008). Testing Slope Homogeneity in Large Panels. Journal of Econometrics, 142, 50-93. https://doi.org/10.1016/j.jeconom.2007.05.010

Phillips, P. C. B., \& Sul, D. (2003). Dynamic Panel Estimation and Homogeneity Testing Under Cross Section Dependence. Econometrics Journal, 6, 217-259. https://doi.org/10.1111/1368-423X.00108

Phillips, P. C. B., \& Sul, D. (2007). Bias in Dynamic Panel Estimation with Fixed Effects, Incidental Trends and Cross Section Dependence. Journal of Econometrics, 137, 162-188. https://doi.org/10.1016/j.jeconom.2006.03.009

Rogoff, K. (1996). The Purchasing Power Parity Puzzle. Journal of Economic Literature, 34, 647-668.

Schmitt-Grohe, S., \& Uribe, M. (2015). How Important are Terms of Trade Shocks? NBER Working Paper 21253.

Shousha, S. (2015). Macroeconomic Effects of Commodity Booms and Busts: The Role of Financial Frictions. Working paper, Columbia University.

Simões, O. R., \& Marçal, E. F. (2012). Agregação Temporal e Não-Linearidade Afetam os Testes da Paridade do Poder de Compra: Evidência a Partir de Dados Brasileiros. Revista Brasileira de Economia, 66, 375-399. https://doi.org/10.1590/S0034-71402012000300006

Sonora, R. J. (2005). City CPI Convergence in Mexico. Review of Development Economics, 9, 359-367. https://doi.org/10.1111/j.1467-9361.2005.00281.x 
Taylor, A. M. (2001). Potential Pitfalls for the PPP Puzzle? Sampling and Specification Biases in Mean-reversion Tests of the Law of One Price. Econometrica, 69, 473-498. https://doi.org/10.1111/1468-0262.00199

Taylor, A., \& Taylor, M. (2004). The Purchasing Power Parity Debate. Journal of Economic Perspectives, 18, 135-158. https://doi.org/10.1257/0895330042632744

Wei, S-J., \& Parsley, D. C. (1995). Purchasing Power Disparity during the Floating Rate Period: Exchange Rate Volatility, Trade Barriers and Other Culprits. Working Paper, National Bureau of Economic Research. https://doi.org/10.3386/w5032

Zini Jr., Á. A., \& Cati, R. C. (1993). Co-integração e Taxa de Câmbio: Testes sobre a PPP e os Termos de Troca do Brasil de 1855 a 1990. Pesquisa e Planejamento Econômico, 23, 349-374.

\section{Notes}

Note 1 . In practice, measured by price indexes.

Note 2. Frankel and Rose (1995) and Wei and Parsley (1995) are the seminal works.

Note 3. It is known that to a large extent the problems described are not completely eliminated by using city-level data, but their effects on the diversions from PPP are attenuated. For consumption baskets, for example, it is very reasonable to assume they are much less heterogeneous within a country than between countries.

Note 4. Half-life is the main metric of the convergence speed of prices. It indicates how long a time series takes to reach half reversion to the mean. See Imbs et al. (2005).

Note 5. This plan, which introduced the present Brazilian currency, the Real, finally ended years of high inflation (at times hyperinflation), interspersed with brief periods of stability resulting from other, ultimately ineffective, economic stabilization plans.

Note 6. This hypothesis involves differences in productivity growth of domestic sectors of tradable and non-tradable goods as generators of differences of inflation, altering the structure of internal prices.

Note 7. Analyzing data for 21 OECD countries, they observed that cross-sectional heterogeneity of the rate of convergence to PPP does not appear to be a quantitatively important source of bias. When simultaneously controlling for the other sources of bias, the estimations produced a median half-life of 3 years.

Note 8. For national data, several studies apply unit root and cointegration tests to time series on the real exchange rate and relative prices between countries. For example Among them, we can mention Zini Jr. and Cati (1993), Holland and Valls Pereira (1999), Kannebley Jr. (2003), Marçal, Valls Pereira and Santos Filho (2003), Freixo and Barbosa (2004), Barbosa (2009), Palaia and Holland (2010) and Simões and Marçal (2012). The results, especially regarding the absolute version of PPP, are widely divergent in function of the time interval analyzed, the testing procedure chosen and the real exchange rate measure.

Note 9. Belém, Belo Horizonte, Brasília, Curitiba, Fortaleza, Goiânia, Porto Alegre, Recife, Rio de Janeiro, Salvador and São Paulo.

Note 10. This is the case of the IPCA, even with monthly frequency, because the sub-items of the index are obtained by as the simple arithmetic mean of the prices collected in different time periods during the month (IBGE, 2013).

Note 11. Appropriately chosen here means according to information criterion measures, such as the BIC, AIC or HQ. With monthly data there are usually more lags in the autoregressive model.

Note 12 . This hypothesis is theoretically very strong, but it is necessary to reach a single value for the half-life in a panel. In practice, authors have reported that it is not a highly relevant hypothesis. See Nath and Sakar (2014) and CMS (2006).

Note 13. For higher order autoregressive processes, equation (5) is only an approximation. For more details, see Nath and Sakar (2014).

Note 14. São Paulo is the largest and richest city in Brazil, its GDP represents $32 \%$ of the Brazilian GDP. The results with the other cities as numeraire were similar and are available upon request.

\section{Copyrights}

Copyright for this article is retained by the author(s), with first publication rights granted to the journal.

This is an open-access article distributed under the terms and conditions of the Creative Commons Attribution license (http://creativecommons.org/licenses/by/4.0/). 